\title{
Correction to: "We can't carry the weight of the whole world": Illness experiences among Peruvian older adults with symptoms of depression and anxiety
}

\author{
Oscar Flores-Flores ${ }^{1,2^{*}}$, Alejandro Zevallos-Morales ${ }^{3}$, Ivonne Carrión ${ }^{3}$, Dalia Pawer ${ }^{3}$, Lorena Rey ${ }^{4}$, \\ William Checkley ${ }^{5,6,7}$, John R. Hurst ${ }^{8}$, Trishul Siddharthan ${ }^{5,6,7}$, Jose F. Parodi ${ }^{1}$, Joseph J. Gallo ${ }^{9,10}$ \\ and Suzanne L. Pollard ${ }^{5,6,7}$
}

\section{Correction to: Int J Ment Health Syst (2020) 14:49 https://doi.org/10.1186/s13033-020-00381-8} Unfortunately, in the original publication of the article, the sixth, seventh and eighth authors' first names in the author group were published in abbreviated form as "W. Checkley, J. R. Hurst, T. Siddharthan". The first name of the authors should be spelled out and should appear in full form as "William Checkley, John R. Hurst, Trishul Siddharthan".

\footnotetext{
Author details

${ }^{1}$ Facultad de Medicina Humana, Centro de Investigación del Envejecimiento (CIEN), Universidad de San Martin de Porres, Lima, Peru. ${ }^{2}$ Asociación Benéfica PRISMA, Lima, Peru. ${ }^{3}$ Facultad de Medicina Humana, Universidad de San Martin de Porres, Lima, Peru. ${ }^{4}$ Pontificia Universidad Católica del Perú, Lima, Peru. ${ }^{5}$ Division of Pulmonary and Critical Care, School of Medicine, Johns Hopkins University, Baltimore, MD, USA. ${ }^{6}$ Department of International Health, Bloomberg School of Public Health, Johns Hopkins University, Baltimore, MD, USA. ${ }^{7}$ Center for Global Non-Communicable Disease Research and Training, School of Medicine, Johns Hopkins University, Baltimore, MD, USA. ${ }^{8}$ UCL Respiratory, University College London, London, UK. ${ }^{9}$ Department of Mental Health, Bloomberg School of Public Health, Baltimore, MD, USA. ${ }^{10}$ Department of General Internal Medicine, School of Medicine, Johns Hopkins University, Baltimore, MD, USA.
}

Published online: 17 September 2020

\section{Reference}

1. Flores-Flores O, Zevallos-Morales A, Carrión I, Pawer D, Rey L, Checkley W, Hurst JR, Siddharthan T, Parodi JF, Gallo JJ, Pollard SL. Correction to: "We can't carry the weight of the whole world": Illness experiences among Peruvian older adults with symptoms of depression and anxiety. Int J Ment Health Syst. 2020;14:49. https://doi.org/10.1186/s13033-020-00381 $-8$.

\section{Publisher's Note}

Springer Nature remains neutral with regard to jurisdictional claims in published maps and institutional affiliations.

The original article can be found online at https://doi.org/10.1186/s1303 3-020-00381-8.

${ }^{*}$ Correspondence: ofloresf@usmp.pe

${ }^{1}$ Facultad de Medicina Humana, Centro de Investigación del

Envejecimiento (CIEN), Universidad de San Martin de Porres, Lima, Peru

Full list of author information is available at the end of the article

\section{$\triangle B M C$}

(c) The Author(s) 2020. This article is licensed under a Creative Commons Attribution 4.0 International License, which permits use, sharing, adaptation, distribution and reproduction in any medium or format, as long as you give appropriate credit to the original author(s) and the source, provide a link to the Creative Commons licence, and indicate if changes were made. The images or other third party material in this article are included in the article's Creative Commons licence, unless indicated otherwise in a credit line to the material. If material is not included in the article's Creative Commons licence and your intended use is not permitted by statutory regulation or exceeds the permitted use, you will need to obtain permission directly from the copyright holder. To view a copy of this licence, visit http://creativecommons.org/licenses/by/4.0/. The Creative Commons Public Domain Dedication waiver (http://creativecommons.org/publicdomain/zero/1.0/) applies to the data made available in this article, unless otherwise stated in a credit line to the data. 